\section{FLUORESCENCE LIFETIME MEASUREMENTS OF SM:YAG AND POTENTIAL USE AS AN OPTICAL THERMOMETER}

N. J. Hess

G. J. Exarhos

S. M. Wood

December 1991

Presented at the American Geophysical Union

Fal1 Meeting 1991

December 3-9, 1991

San Francisco, California

Work supported by the U.S. Department of Energy under Contract DE-AC06-76RLO 1830

Pacific Northwest Laboratory Richland, Washington 99352

\title{
DISCLAIMER
}

\begin{abstract}
This report was prepared as an account of work sponsored by an agency of the United States Government. Neither the United States Gnvernment nor any agency thereof, nor any of their employees, makes any warranty, express or implied, or assumes any legal iiability or responsibility for the accuracy, completeness, or usefulness of any information, apparatus, product, or process disclosed, or epresents that its use would not infringe privately owned rights. Reference herein to any specific commercial product, process, or service by trade name, trademark, manufacturer, or otherwise does not necessarily constitute or imply its endorsement, recommendation, or favoring by the United States Government or any agency thereof. The views and opinions of authors expressed herein do not necessarily state or reflect those of the United States Government or any agency thereof.
\end{abstract}


Fluorescence Lifetime Measurements of Sm:YAG and Potential use as an Optical Thermometer

NJ Hess and GJ Exarhos (Pacific Northwest Laboratory, Richland WA 99352)

S Wood (Shock Dynamics Laboratory, Washington State University, Pullman WA 99163)

In situ phase equilibrium studies require a means of accurate pressure and temperature measurement. Earlier work has demonstrated that the frequency shift of the laser-induced fluorescence of samarium-doped yttrium aluminum garnet, Sm:YAG, can be used without temperature correction as a pressure sensor for high temperature diamond anvil cell experiments. Reported here are the results of preliminary studies on the temperature and pressure dependence of the Sm:YAG fluorescence lifetime and its use as a possible optical thermometer.

The lifetime of laser-induced fluorescence of Sm:YAG was measured as a function of Sm dopant concentration, temperature, and pressure using the phase modulation technique. The Sm dopant concentration was varied between 0.1 to $3.0 \%$ mole fraction $Y$ in crystalline powders prepared from a metal nitrate precursor solution. The temperature dependence of the lifetime was measured between 20 and $1200^{\circ} \mathrm{C}$. For all depant concentrations, a similar temperature dependence is observed; namely, at low temperature the lifetime is insensitive to temperature and at higher temperature the lifetime decreases sharply. In addition, the temperature at which the lifetime becomes strongly temperature dependent varies with dopant concentration. Preliminary high pressure studies indicate the lifetime of Sm:YAG is relatively unchanged to $40 \mathrm{kbar}$. These results suggest that the Sm:YAG fluorescence lifetime may be a promising optical thermometer for high pressure experiments and that the region of temperature sensitivity can be "tuned" by varying the dopant concentration.
1. 1991 Fall meeting

2. 009269781

3. (a) NJ Hess

Battelle

PO Box 999, K2-44

Richland WA 99325

(b) $509375-2142$

(c) $509375-2186$

4. V

5. (a) Mineral Physics

(b) 3994 Instruments and techniques 3924 High-pressure behavior

(c) Mineral Physics

6.

7. $0 \%$

8. $\$ 60.00$

MC: 5425180205255547

exp: $6 / 93$

Nancy J. Hess

9. c

10. yes

11. no 

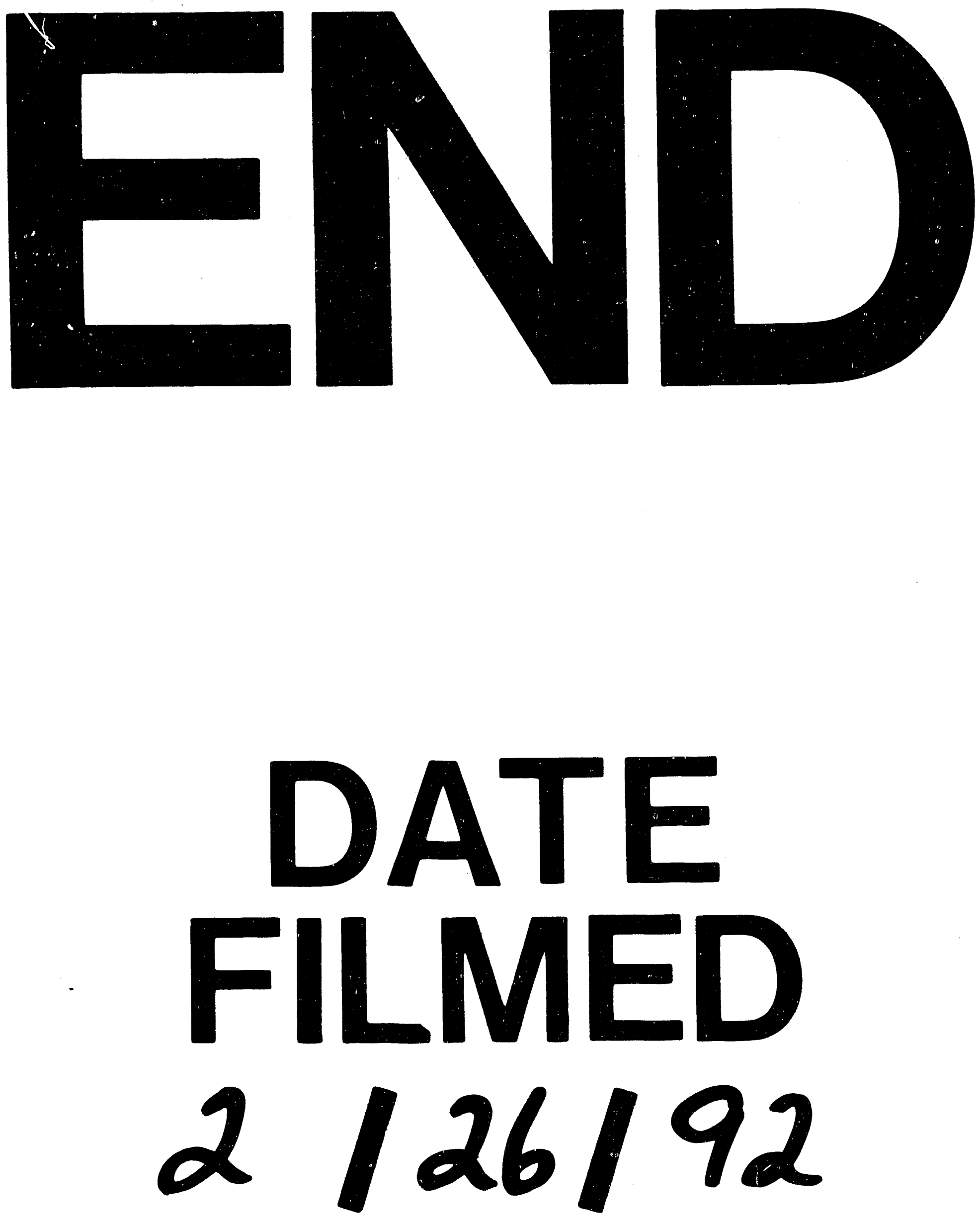
